\title{
ВНЕСОК МУЗИКОЗНАВЦІВ У РОЗБУДОВУ НАУКОВОГО ТОВАРИСТВА ІМЕНІ ШЕВЧЕНКА В ДІАСПОРІ
}

\author{
Карась Г. В.
}

\section{ВСТУП}

Наукове товариство імені Шевченка (далі - НТШ) - усесвітня українська академічна організація, багатопрофільна академія наук українського народу, що була створена 23 грудня 1873 р. у Львові, в умовах бездержавності слугувала рушійною силою формування та розвитку української науки кінця XIX - першої половини XX ст. В українській історії - це перша суспільна установа, яка, сповідуючи Шевченкові ідеї служіння Україні, присвоїла собі його ім'я. Товариство за оновленим статутом, ухваленим у 1892 р., перетворилося на багатопрофільну академію наук - із пріоритетом проблем українознавства ${ }^{1}$. Якщо в 1920-1930-х рр. Товариство зазнавало переслідувань від польської влади, то в 1939 р. було зліквідоване радянською владою і відновило свою діяльність в Україні в 1989 р., напередодні проголошення Незалежності. У проміжку цих п’ятдесяти років НТШ діяло в діаспорі, відновившись після Другої світової війни в 1947 р. у Мюнхені (Західна Німеччина) та США (де стало відоме як Shevchenko Scientific Society), згодом у Канаді (1949 р.) і Австралії (1950р.). Як НТШ Свропи Товариство працює 31952 р. в Сарселі (Франція). Структура Товариства передбачала діяльність секцій та комісій. Так, музикознавча комісія НТШ, яка була створена у Львові в 1935 р., входила до складу історико-філософічної секції. До неї ввійшли провідні науковці того часу, а саме: С. Людкевич (голова комісіі), 3. Лисько (заступник голови), В. Витвицький, В. Барвінський, Б. Кудрик, Ф. Колесса, Н. Нижанківський, С. Туркевич-Лукіянович, Є. Цегельський. Нещодавно вперше опубліковані Якимом Гораком протоколи засідань комісії ${ }^{2}$, які не тільки увиразнюють організаційну, наукову діяльність музикознавців, але й допомагають зрозуміти тяглість традицій науки в діаспорі, оскільки частина з них у часі Другої світової війни емігрували на Захід. Високий освітній та науковий рівень українських музикознавців діаспори забезпечувався їх навчанням та становленням у провідних музичних закладах України, Росії, країн Європи, США та Канади.

\footnotetext{
1 Наукове товариство імені Шевченка. URL: https://uk.wikipedia.org/wiki/Наукове_товариство_ імені Шевченка.

2 Горак Я. Протоколи засідань музикознавчої комісії НТШ. Українська музика. Львів, 2018. № 2 (28). C. 121-134.
} 
Сучасна українська музикознавча наука, яка пройшла складний шлях становлення у XX ст., як підсистема духовної культури та системне явище, репрезентована багатьма науковими дисциплінами, сферами, низкою проблемно-тематичних напрямів. Відтворення цілісності українського музикознавства актуалізує вивчення його діаспорної вітки, зокрема в контексті діяльності НТШ. Якщо про діяльність НТШ в Україні та діаспорі написано багато праць і досліджень, то про діяльність музикознавців в iï лоні є лише окремі згадки. Уперше цей аспект частково висвітлений у нашій монографії ${ }^{3}$, дослідженнях Олени Немкович ${ }^{4}$, Оксани Гнатишин ${ }^{5}$ та Уляни Граб ${ }^{6}$. Тому основною метою нашої розвідки є з'ясування внеску музикознавців у розбудову Наукового товариства імені Шевченка в діаспорі.

\section{1. Чільні постаті українського музикознавства діаспори} повоснного періоду та науково-дослідний напрям їх діяльності

Основними сферами наукових розмислів музикознавців діаспори після закінчення Другої світової війни були медієвістика, історія церковної музики, зокрема української, біографістика. Тоді як в атеїстичній радянській Україні ці теми були табуйованими, значним внеском у розвиток української музикознавчої науки стають праці М. Антоновича (Нідерланди) П. Маценка (Канада), В. Витвицького, А. Рудницького, I. Соневицького (усі - у США).

Наукові дослідження Мирослава Антоновича (1917-2006 pp.) зосереджені навколо давньої церковної музики, передусім української та франко-фламандської. Як підкреслює О. Гнатишин, «із тріади своїх зацікавлень українською музикою - монодією, партесним багатоголоссям, новітньою творчістю - М. Антонович найбільшу увагу присвятив гимнографії $<\ldots>>{ }^{7}$. В Утрехтському університеті науковець успішно захистив докторську працю про творчість Жоскена де Пре, одного 3 найяскравіших представників франко-фламандської школи доби Відродження (1951р.), і залишається тут працювати науковим співробітником Інституту музикознавства. Згодом він спричиниться до першого новітнього видання творів цього композитора і буде визнаний одним із кращих знавців творчості Жоскена де Пре в Європі. У монографії про українську церковну музику він описує колекцію

\footnotetext{
${ }^{3}$ Карась Г. Музична культура української діаспори у світовому часопросторі XX ст. : монографія. Івано-Франківськ : Тіповіт, 2012. 1164 с.

${ }^{4}$ Немкович О. Українське музикознавство XX ст. як система наукових дисциплін : монографія. Київ, 2006. 534 с.

Гнатишин О. Історичний вимір українських музично-теоретичних концепцій : монографія. 2-ге вид. Львів : Вид-во Львівської політехніки, 2018. 600 с.

6 Граб У. Мирослав Антонович : інтелектуальна біографія. Еміграційне музикознавство 6 украӥнському культуротворенні повоснних десятиліть : монографія. Львів : Вид-во Українського католицького університету, 2018. 456 с.

7 Гнатишин О. Історичний вимір українських музично-теоретичних концепцій : монографія. 2-ге вид. Львів : Вид-во Львівської політехніки, 2018. С. 133. 
Ірмологіонів за мікрофільмами бібліотеки Народової у Варшаві ${ }^{8}$, уперше в українській історіографії дає повну i всебічну характеристику українського Ірмологіона як антології гимнографічних співів . П'ятиголоса партесна Служба Божа невідомого автора XVII ст., яку музикознавець віднайшов у Сербії, здійснив тї транскрипцію i публікацію за участю П. Маценка та С. Яременка, явила світові високі досягнення українського духовного мистецтва ${ }^{10}$. Музиколог пише розвідки про неї, а також про українську церковну музику, візантійську літургійну музику, історію українського та російського церковного співу ${ }^{11}$, низка статей ученого присвячені історії української церковної музики ${ }^{12}$. Свідченням вагомості наукового доробку М. Антоновича $\epsilon$ дослідження музикознавиці Уляни Граб ${ }^{13}$. Публікація монографії та захист ії докторської монографії (2019р.) відкрили цю потужну постать для українського наукового світу. Учена аналізує інтелектуальну працю М. Антоновича на перехресті Сходу і Заходу, виокремлює два напрями його досліджень - західноєвропейську музику Ренесансу й українську церковну музику. Оскільки в цей час в радянській Україні медієвістичних досліджень не проводилось, то діяльність М. Антоновича набуває особливого значення. Він поряд з іншими музикознавцями діаспори продовжував тяглість наукової традиції вивчення давньої літургійної музики. О. Гнатишин підкреслює: «<... Глобальною

\footnotetext{
${ }^{8}$ Antonowytcz M. Ukrainische geistliche Musik. München, 1990. 374 S.

9 Антонович M. Musica sacra : збірник статей з історії української церковної музики / упор., наук. ред., передмова Ю. Ясиновський. Львів : Ін-т українознавства ім. І. Крип'якевича НАН України, 1997. $261 \mathrm{c}$.

${ }^{10}$ П’ятиголосна партесна Служба Божа невідомого автора / транскрипція та зведення в партитуру М. Антонович ; ред. П. Маценко ; передрук музики С. Яременко. Вінніпег : видання Колегії Св. Андрея у Вінніпезі при Манітобському ун-ті, 1979. 79 с.

${ }^{11}$ Антонович М. П’ятиголосна партесна Літургія - пам'ятка української музичної культури доби бароко. Записки Наукового товариства імені Шевченка: прачі музикознавчої комісї. T. CCXXVI / ред. : О. Купчинський, Ю. Ясиновський. Львів, 1993. С. 57-74 ; Antonowytcz M. Die motette Benedicta es von Josquin des Prez und die Messen super Benedicta von Willaert, Palestrina, de la Hêle und de Monte. Utrecht, 1951. 126 S. ; Antonowytcz M. The Chants from Ukrainian Heirmologia. Bilthowen, 1974. 203 S. ; Antonowytcz M. Ukrainische geistliche Musik. Műnchen, 1990. 374 S. ; Antonowytcz M. Oekraïne en de Bezantijnse ritus. Hoensbroek, 2000. 367 Blz.

${ }_{12}$ Антонович М. Дещо про українську церковну монодію та про назви «знаменний» і «київський» розспів. Науковий збірник Украйнського вільного університету. Т. Х. Мюнхен, 1983. С. 147-170; Антонович M. Значення української партесної музики для російської музичної культури XVII-XVIII ст. Збірник на пошану Григорія Китастого / упоряд. і редакція Я. Гурського. Нью-Йорк, 1980. С. 39-55 ; Антонович М. Питоменності українського церковного співу. Збірник праць Ювілейного конгресу : Науковий конгрес у 1000-ліття Хрищення Руси-України у співпраці 3 Украӥнським вільним університетом / ред. В. Янів. Мюнхен, 1988-1989. С. 458-474 ; Антонович М. Поліфонічна музика в українських церквах у добі Козаччини. INTREPIDO PASTORI : науковий збірник на честь Блаженнішого Патріарха Йсифа в 40-ліття вступлення на галицький престіл. 01.11.1944. Рим, 1984. С. 595-612 ; Антонович М. П’ятиголосна партесна Літургія - пам'ятка української музичної культури доби до Бортнянського. Богословія. Рим, 1973. Т. 37. С. 65-88, передрук під назвою «П'ятиголосна партесна Літургія - свідок української музичної культури 3 доби до Бортнянського. П'ятиголосна партесна Служба Божа невідомого автора / транскрипція та зведення в партитуру М. Антонович ; ред. П. Маценко ; передрук музики С. Яременко. Вінніпег : видання Колегії Св. Андрея у Вінніпезі при Манітобському ун-ті, 1979. С. 9-32.

13 Граб У. Мирослав Антонович: інтелектуальна біографія. Еміграційне музикознавство в украӥнському культуротворенні повоєнних десятиліть : монографія. Львів : Вид-во Українського католицького університету, 2018. 456 с.
} 
концептуальною ідеєю досліджень М. Антоновича є вияв спільності української сакральної монодії 3 іiі візантійською першоосновою, спорідненості з українськими фольклорними джерелами, всезростаючих зв’язків із західноєвропейською музичною стилістикою Ренесансу та Бароко» $^{14}$.

Мистецтвознавчі дослідження Павла Маценка (1897-1991рp.) в основному зосереджені навколо проблем давньої української музики, історії української церковної музики. Уже в дисертації науковця ${ }^{15}$ « ..> виявилася цілком сформована концепція структури і будови співів Ірмологіону» ${ }^{16}$. Згодом він друкує невеликі дослідження про творців української церковної музики М. Березовського, Д. Бортнянського, О. Кошиця ${ }^{17}$, нариси та конспект до історії української церковної музики, розвідку про українські канти ${ }^{18}$. У Ювілейному збірнику наукових праць у 100-річчя НТШ і 25-річчя НТШ у Канаді у 1997 р. знаходимо працю П. Маценка «Українська церковна музика» ${ }^{19}$, яка засвідчує причетність науковця до цієї поважної інституції. Головна заслуга вченого полягає у виокремленні історії походження української церковної музики із загальноісторичної картини російської музики.

Ігорю Соневицькому (1926-2006 рр.) належить перша грунтовна монографія про Артемія Веделя ${ }^{20}$. Він же першим видав духовні твори композитора $^{21}$. Лекції 3 історії української церковної музики, які музикознавець читав для студентів папської семінарії в Римі, збагачують джерельну базу української музикознавчої науки ${ }^{22}$. I. Соневицький одним із перших досліджував композиторську спадщину Нестора Нижанківського $^{23}$. Повна збірка композиторських рукописів пропала у Празі під час Другої світової війни, i впродовж двадцяти років I. Соневицький реконструював доробок Н. Нижанківского шляхом

\footnotetext{
14 Гнатишин О. Історичний вимір українських музично-теоретичних концепцій : монографія 2-ге вид. Львів : Вид-во Львівської політехніки, 2018. С. 136.

15 Маценко П. Склад та технічна будова мелодій київського розспіву в Почаївському ірмолоєві вид. 1775 р. : дис. Відень, 1930-1932. Павло Маценко: Музиколог, композитор і громадський діяч : збірник на пошану 90-ліття народин / упор. і ред В. Верига. Торонто : вид УНО Канади, 1992. С. 127-238.

16 Гнатишин О. Історичний вимір українських музично-теоретичних концепцій : монографія. 2-ге вид. Львів : Вид-во Львівської політехніки, 2018. С. 132.

${ }_{18}^{17}$ Маценко П. Засади творчости О. Кошиця. Вінніпег, 1950. 14 с.

${ }_{18}$ Маценко П. Нариси до історії української церковної музики. Роблин ; Вінніпег : Видання М.Т.Б., 1967. 151 с. ; Маценко П. Нариси 3 історії української церковної музики. Вінніпег : Колегія Св. Андрея у Вінніпезі, 1993. 172 с. ; Маценко П. Нариси до історії української церковної музики. 2-ге репринт. вид. Роблин ; Вінніпег, 1968. Київ : Муз. Україна, 1994. 152 с. ; Маценко П. Українські канти. Вінніпег : накладом Т-ва «Волинь», 1981. 22 с.

19 Маценко П. Українська церковна музика. Ювілейний збірник наукових працьь Канадського Наукового товариства імені Шевченка в 100-річчя Наукового товариства імені Шевченка $i$ у 25-річчя Наукового товариства імені Шевченка в Канаді / ред. Р. Біланюк, Б. Стебельський. Торонто, Онтаріо, Канада : Гомін України, 1997. С. 136-141.

${ }^{20}$ Соневицький I. Артем Ведель і його музична спадщина. УВАН у США. Музикологічна секція. Ротапринт. Нью-Йорк, 1966. 177 с.

21 Духовні твори Артемія Лукіяновича Веделя / ред. І. Соневицький. Нью-Йорк, 1985.

22 Соневицький I. Лекції з історії української церковної музики. Рим, 1975.

23 Соневицький I. Композиторська спадщина Нестора Нижанківського. Рим : Богословія, 1973. Ч. $45.34 \mathrm{c}$.
} 
вивчення інформацій В. Барвінського, періодики, спогадів 3. Лиська, листування із дружиною композитора та діячами музичної культури діаспори, які знали Н. Нижанківского або володіли тими чи іншими матеріалами. У результаті багаторічних пошуків вдалося віднайти понад 80 відсотків творів композитора, які були надіслані вченому з різних країн світу. І. Соневицький упорядкував та відредагував автобіографічні нариси видатного співака Мирослава Скали-Старицького ${ }^{24}$, здійснив запис мелодій і слів пісень Р. Купчинського, випустив їх друком, таким чином зберіг ці пам'ятки пісенної культури ${ }^{25}$, упорядкував та видав хорові твори Івана Недільського ${ }^{26}$.

Василь Витвицький (1905-1999 рр.) видає грунтовні монографії про українських композиторів. У 1954 р. у Нью-Йорку світ побачила праця про Михайла Гайворонського, яка у 2001 р. була перевидана в Україні2 ${ }^{27}$ Це перше і донині, на жаль, єдине монографічне дослідження про цього композитора. Монографія про життя і творчість Максима Березовського теж перевидана в Україні ${ }^{28}$. У рецензії на це видання А. Рудницький ${ }^{29}$ відзначав ясну і сконденсовану форму викладу, багатство подробиць і фактів із життя і творчості М. Березовського, уперше проведений зразковий аналіз його творів, зокрема віднайденої В. Витвицьким скрипкової сонати ${ }^{30}$. Критик уважав монографію цінним внеском В. Витвицького в музикологічну літературу.

У повоєнний час музикознавчу працю продовжує Зіновій Лисько (1895-1969 рр.), займаючись питаннями творчої проблематики української музики, взаємовпливами музичних культур, кобзарським виконавством, музичною лексикографією та біобібліографією, фольклористикою. Учений збирає та систематизує українські народні пісні, створюючи монументальну десятитомну антологію «Українські народні мелодії», яка є найбільшим досягненням діаспорної музичної фольклористики. В. Сивохіп уважає вченого репрезентантом і продовжувачем фольклористичної традиції Ф. Колесси, а його доробок - «важливою сполучною ланкою між класичною етномузикологією першої половини

\footnotetext{
24 Мирослав Скала-Старицький (Miro Skala). Перший тенор Королівської опери «Ля Моне» у Брюсселі : автобіографічні нариси / ред., упоряд. і допов. на основі джерельних матеріалів Ігор Соневицький. Львів, 2000. 95 с.

${ }^{25}$ Купчинський Р. Ми йдемо в бій : повний збірник пісень / записав, упор. і зред. І. Соневицький. Нью-Йорк : Червона калина, 1977. 144 с.

${ }^{26}$ Недільский I. Вибрані твори для мішаного хору а capella / за ред. Ігоря Соневицького. Ню-Йорк : Українська музична фундація, 1982. 98 с.

${ }^{27}$ Витвицький В. Михайло Гайворонський: життя і творчість. Нью-Йорк, 1954. 207 с. ; передрук : Витвицький В. Михайло Гайворонський: життя і творчість / ред. Є. Дзюпина, Ю. Ясіновський. Львів, 2001. 175 c.

${ }^{28}$ Витвицький В. Максим Березовський. Життя і творчість. Джерзі Ситі : Вид-во М.П. Коць, 1974. 95 с. ; передрук : Витвицький В. Максим Березовський. Життя і творчість / ред. колегія : В. Гаюк, Я. Якубяк, Ю. Ясиновський ; наук. ред. Л. Кияновська. Львів : Логос, 1995. 110 с.

29 Рудницький А. 3 нових видань. Витвицький Василь : Максим Березовський. Життя і творчість. Джерзі Ситі : В-во М.П. Коць, 1974. Ст. 94. Свобода. 1975. 29 травня. Ч. 102.

30 В. Витвицький знайшов твір у 1974 р. в Національній бібліотеці в Парижі у вигляді рукопису 3 1771 або $1772 \mathrm{p}$.
} 
XX ст. <..> та найновішою добою приблизно від 60-70-х рр.». ${ }^{31}$ У публіцистичному доробку 3. Лиська цього періоду - аналітичні статті, присвячені діячам української музичної культури: о. П. Бажанському, О. Кошицю, Ф. Якименку, Н. Нижанківському, О. Носалевичу, В. Барвінському, В. Косенку, Р. Придаткевичу, Р. Савицькому, М. Фоменку, які друкувалися на початку 1950-х рр. у Мюнхені у виданнях «Український самостійник», «Християнський голос», «Сучасна Україна».

Музикознавчий i критичний доробок Антона Рудницького (1901-1975 рр.) представлений критичним оглядом «Українська музика», статтями і рецензіями, що увійшли до збірника «Про музику і музик» ${ }^{32}$. Не завжди об'єктивний, часом надто категоричний у твердженнях, особливо коли йдеться про проблеми традиції і новаторства, він часто займав чітку і аргументовану позицію стосовно історичних процесів української музики. В огляді вміщено багатий фактичний матеріал про музичне життя міжвоєнних Львова та Києва, української спільноти у світі. Багатожанровий музикознавчий та публіцистичний доробок А. Рудницького $\epsilon$ важливою складовою частиною української музичної культури діаспори, цінним джерелом для іiї вивчення.

Музикознавці діаспори часто зверталися до життя i творчості українських та закордонних композиторів, а тому музична біографістика широко представлена в їхньому науково-публіцистичному доробку. Окрім вищеназваних праць музикознавців діаспори, назвемо дослідження Мирослава Антоновича про О. Кошиця та С. Людкевича ${ }^{33}$, Павла Маценка - про Ф. Якименка, С. Яременка, засади творчості О. Кошиця ${ }^{34}$, Івана Коваліва - про В. Барвінського ${ }^{35}$, Теодора Терен-Юськів - про національно-державну мотивацію творчості С. Людкевича ${ }^{36}$. Серед інших досліджень доповідь А. Шуля про В. Витвицького як музикологакультуролога ${ }^{37}$, стаття композитора Ю. Фіяли про проблеми сучасної музичної творчості ${ }^{38}$.

\footnotetext{
31 Сивохіп В. Етномузиколог Зиновій Лисько - репрезентант і продовжувач фольклористичної традиції Філарета Колесси. Родина Колессів у духовному та культурному житті Украйни кінця XIXXX cm. (з нагоди 130-річчя від дня народження академіка Філарета Колесси та 100-річчя від дня народження академіка Миколи Колесси) : збірник наукових праць та матеріалів. Львів, 2005. С. 229.

32 Рудницький А. Українська музика : історико-критичний огляд. Мюнхен : Дніпрова хвиля, 1963. 406 с. ; Рудницький А. Про музику і музик. Ню-Йорк ; Париж ; Сідней ; Торонто : НТШ, Б-ка українознавства, 1980. Ч. 39. 336 с.

${ }_{33}$ Антонович М. Кошиць Олександер Антонович - композитор церковної музики і диригент / відп. ред. П. Маценко. Вінніпег, 1975. 96 с. ; Антонович М. Станислав Людкевич: композитор, музиколог. Рим, 1980. 68 с. ; Антонович М. Станислав Людкевич: композитор, музиколог / наук. ред., біографічна нотатка про М. Антонтовича Ю. Ясиновський. Львів : Спілка композиторів України, 1999. 60 с. ; Антонович М. Станислав Людкевич: композитор, музиколог. Львів : Veritas, 2007. 64 с.

34 Маценко П. Якименко Федір Степанович. Вінніпег : ОУКО, 1954. 18 с. ; Маценко П. С. Яременко - композитор. Вінніпег : Новий шлях, 1974. 32 с.

35 Ковалів І. Василь Барвінський: нарис життя і творчості. Торонто : Муз. ін-т ім. М. Лисенка, 1964. $13 \mathrm{c}$.

36 Терен-Юськів Т. Національно-державна мотивація творчості С. Людкевича. Лондон : Укр. видавн. спілка, 1984. 80 с.

${ }^{37}$ Шуль А. Д-р Василь Витвицький: музикознавець як культуролог : доповідь на Конференції в пошану В. Витвицького (машинопис). Нью-Йорк, 2001. 31 березня.

38 Фіяла Ю. Сучасний композитор і проблеми музичної творчости ХХ ст. Сучасність. Мюнхен, 1982. Ч. 4-5 (256-257). С. 92-103.
} 
Представником молодшої генерації етномузикологів Канади є Браєн Черевик (1960р.н.). Він - не лише знаний музикант, але й учений: здобув академічний магістерський та докторський ступені в етномузикознавстві й українській фольклористиці в університеті Альберти, є член-кореспондентом НТШ Канади (секція мистецтвознавства). Його статті присвячені дослідженню української інструментальної музики в Альберті (Західна Канада) $)^{39}$. Учений зібрав унікальні дані про окремих виконавців на народних інструментах, починаючи 3 кінця XIX ст. Магістерська робота Б. Черевика 3 українського фольклору присвячена українським цимбалам в Альберті ${ }^{40}$. Праця вченого на здобуття ступеня доктора етномузикології та української фольклористики, яка була захищена в університеті Альберти (1999р.), присвячена українській музиці як засобу розбудови ідентичності українців у Канаді ${ }^{41}$.

Отже, музикознавство діаспори повоєнного періоду представлено чільними постатями, які зробили вагомий внесок у розвиток цього напряму гуманітарної науки.

\section{2. Участь музикознавців в укладанні енциклопедій} та енциклопедії українознавства

НТШ у Сарселі зосередило свої зусилля на виданні «Енциклопедіi украӥнознавства» (далі - ЕУ), 1949-1989 рр., активну участь в якому брали музикознавці Василь Витвицький, Зіновій Лисько, Андрій Ольховський. «Енциклопедія українознавства» (англ. Encyclopedia of Ukraine) - фундаментальна праця 3 україністики, яка складається із 14 томів. За аналогією з Encyclopedia Britannica, томи ЕУ кількох типів. Перший тип - це три томи так званої "Macropedia" (1949р.), також відомі як ЕУ-I, де фактично розміщена одна велика розлога стаття про Україну на 1200 сторінок (нумерація всіх трьох томів наскрізна). Другий тип - це 10 томів так званої "Micropedia" (1955-1995рр.), також відомих як ЕУ-II, де вміщено короткі статті та плюс 11-ий т. із виправленнями та доповненнями. Усього енциклопедія містить понад

\footnotetext{
39 Черевик Б. Звуки прерій : виставка, присвячена українській інстументальній музиці в Альберті. Західноканадський збірник. Ч. 5 / ред. М. Сорока. Едмонтон - Острог, 2008. С. 451-455 ; Черевик Б. Українська інструментальна музика в Альберті. Західноканадський збірник. Ч. 4 / упор. Яр Славутич. Едмонтон : Канадське НТШ ; Друкарня Видав. спілки «Гомону України», 2000. С. 325-342 ; Cherwick В. Muzyky: Ukrainian bands in Western Canada. Міграційні рухи із Західної України до Західної Канади : матеріали спільних конференцій : Міжнародної конференції «Еміграція населення західноукраїнських земель до Північної Америки на рубежі XIX-XX ст. Ї̈ роль в освоєнні канадського заходу». До 100-річчя української еміграції, м. Чернівці, 1990 р. / ред. : О. Макар, Р. Білаш. Едмонтон : Канадський центр української культури та етнографії ; Альбертський університет ; Відділ охорони історичних пам'яток ; Міністерство громадського розвитку Альберти, 2002. С. 299-305.

${ }^{40}$ Cherwick B. The Ukrainian Tsymbaly: Hammered Dulcimer Playing Among Ukrainians in Alberta: in partial fulfillment of the requirements for the degree of Master of Arts in Ukrainian Folklore. University of Alberta. Canada, 1992. 147 p.

${ }^{41}$ Cherwick B. Polkas on the Prairies: Ukrainian Music and the Construction of Identity. Doctor of Philosophy. University of Alberta. Canada, 1999. 226 p.
} 
20000 термінів. У 1984-1993 рр. була видана англомовна скорочена версія, що складається з 5-ти томів та містить лише 12500 термінів.

Музикознавці В. Витвицький, 3. Лисько, А. Ольховський написали музичні статті до ЕУ, що вийшла друком українською мовою в Мюнхені в 1949 р., англійською - у Торонто (Канада) у 1960-х рр. Керівництво підготовкою матеріалів та зв'язок із головною редакцією ЕУ здійснював 3. Лисько. Автори постійно контактували, а 20 серпня 1948 р. з'їхалися 3 готовими статтями для їх обговорення. Як згадував В. Витвицький, «взаємний обмін думок і зауважень виявився дуже корисним» ${ }^{42}$.

Василь Витвицький підготував до загальної частини ЕУ дві статті. Оглядаючи розвиток української музики протягом двох століть $(\text { XVIII-XIX ст. })^{43}$, музикознавець звертає увагу насамперед на церковну музику (поява першого друкованого Ірмолоя 1707 р., творення церковнонародних пісень - кантів та псалмів, творчість українських композиторів М. Березовського, А. Веделя та Д. Бортнянського, композиторів Галичини - М. Вербицького й І. Лаврівського). Висвітлюючи світську музику, В. Витвицький здійснює огляд музики для театру, творчість композиторів С. Гулака-Артемовського, П. Ніщинського, П. Сокальського, М. Лисенка, водночас не залишає поза увагою творчість композиторів Галичини. Музичне виконавство автор розглядає в широкому контексті - від організації музичних цехів XVII-XVIII ст. до творчості видатних українських виконавців - співаків, інструменталістів, диригентів, окремих колективів як в Україні, так і за іiі межами ${ }^{44}$. Двадцять років безоплатної праці музикознавець віддав співпраці 3 редакцією ЕУ в Сарселі (Франція), де був співробітником редакції, а пізніше керівником іiї музичної секції, заступивши Зіновія Лиська.

Перу Зіновія Лиська належать три статті: про народну музику, про український гімн та історію української музики XI-XVII ст. Українському гімну «Ще не вмерла Україна» присвячена невеличка стаття оглядового характеру з додатком мелодії твору ${ }^{45}$. Стаття вченого про українську народну музику стала свідченням визнання його авторитету як фольклориста ${ }^{46} . \mathrm{У}$ ній автор подає різні типи, стилі та

\footnotetext{
42 Витвицький В. Музикознавець Андрій Ольховський (1900-1969). Сучасність. 1978. № № 7-8. C. 194.

${ }^{43}$ Витвицький В. Історія музики. XVIII-XIX ст. Енииклопедія украӥнознавства. Загальна частина. Репринтне відтворення видання 1949 р. Перевидання в Україні. Київ : Віпол, 1995. Т. 3. С. 869-873; Wytwycky W. History of Ukrainian Music. Eighteenth and Nineteenth Centuries. Ukraine. A Concise Encyclopaedia / Edit. by V. Kubiiovyč. University of Toronto pres, 1971. Vol. II. P. 582-588.

44 Витвицький В. Музичне виконавство. Енииклопедія украйнознавства. Загальна частина. Репринтне відтворення видання 1949 р. Перевидання в Україні. Київ : Віпол, 1995. Т. 3. С. 876-879 ; Wytwycky W. Musical performance. Ukraine. A Concise Encyclopaedia / Edit. by V. Kubijovyč. University of Toronto pres, 1971. Vol. II. P. 593-600.

45 Лисько 3. Український гімн. Енииклопедія украӥнознавства. Загальна частина. Репринтне відтворення видання 1949 р. Перевидання в Україні. Київ : Віпол, 1994. Т. 1. С. 33-34.

46 Лисько 3. Народна музика. Енииклопедія украйнознавства. Загальна частина. Репринтне відтворення видання 1949 р. Перевидання в Україні. Київ : Віпол, 1994. Т. 1. С. 273-279 ; Lvsko Z. Folk music. Ukraine. A Concise Encyclopaedia / Edit. by V. Kubijovyč. Toronto : University of Toronto pres, 1963. Vol. I. P. 371-378.
} 
музичні системи української пісенності та танкові форми в інструментальній і вокальній музиці. Лаконічна за формою, але вагома за змістом стаття залишається досі важливим інформаційним джерелом про народну музику. У статті про українську музику XI-XVII ст. 3. Лисько звертає увагу на світську та церковну музику вказаного періоду, розвиток нотації, хорове й інструментальне виконавство 47 .

Андрій Ольховський (в українському виданні під псевдонімом Свген Оленський) пише до ЕУ дві статті ${ }^{48}$. Розвиток музикознавства вчений розглядає в контексті розвитку музичного шкільництва від Глухівської школи (1737 р.) до 1950-х рр., не оминаючи внеску музикознавців діаспори в цей процес. Більш об’ємною й аналітичною є стаття А. Ольховського про розвиток української музики ХX ст., у якій зроблено аналіз нового етапу розвитку української музики за першу половину століття в контексті соціокультурних умов в Україні та за їі межами. Учений зазначає, що динаміка цього процесу на початку століття у творчості композиторів М. Лисенка, К. Стеценка, Я. Степового, М. Леонтовича, П. Сениці, О. Кошиця й ін. із приходом більшовиків уповільнилася, а мистецтво перетворилося на прикладний засіб політпропаганди, 3 нього вихолощувалося все національне. Незважаючи на ці обставини, автор відзначає, що українська музика 1920-1930-х рр. вражає різноманітністю жанрів, опануванням засобів великої масштабної форми. Перелічивши кращі твори цього періоду, він наголошує: «Така дозрілість цілісного прояву укр. муз. творчости, як нац. своєрідної системи звуковідчуття стверджується також фактом майже одночасної появи, поруч із цими творами, творів великої ідейної наснаги, масштабної форми та зрілого професіоналізму і композиторів львівської групи $<\ldots>>{ }^{49}$. Щодо композиторів діаспори, автор називає чільні постаті й окремі твори, не вдаючись до їх оцінки.

В енциклопедії вміщено статтю Нестора Нижанківського про українські народні музичні інструменти з їх описами та зображеннями, міркування про збірне музикування ${ }^{50}$.

47 Лисько 3. Історія музики. XI-XVII ст. Енциклопедія українознавства. Загальна частина. Репринтне відтворення видання 1949 р. Перевидання в Україні. Київ : Віпол, 1995. Т. 3. С. 868-869; Lysko Z. History of Ukrainian Music : Eleventh to Seventeenth Centuries. Ukraine. A Concise Encyclopaedia / Edit. by V. Kubijovyč. Toronto : University of Toronto Press, 1971. Vol. II. P. 579-582.

48 Оленський Є. Історія музики. XX ст. Енииклопедія украӥнознавства. Загальна частина. Репринтне відтворення видання 1949 р. Перевидання в Україні. Київ : Віпол, 1995. Т. 3. С. 873-876; Оленський С. Музикознавство і музичне шкільництво. Енииклопедія украӥнознавства. Загальна частина. Репринтне відтворення видання 1949 р. Перевидання в Україні. Київ : Віпол, 1995. Т. 3. C. 866-868 ; Olkhovsky A. History of Ukrainian Music : Twentieth Century. Ukraine. A Concise Encyclopaedia / Edit. by V. Kubijovyč. Toronto : University of Toronto Press, 1971. Vol. II. P. 588-593 ; Olkhovsky A. Musical education; Musicology. Ukraine. A Concise Encyclopaedia / Edit. by V. Kubijovyč. Toronto : University of Toronto Press, 1971. Vol. II. P. 582-588, 593-600.

49 Оленський С. Історія музики. ХX ст. Енциклопедія украӥнознавства. Загальна частина. Репринтне відтворення видання 1949 р. Перевидання в Україні. Київ : Віпол, 1995. Т. 3. С. 875.

50 Нижанківський Н. Народні музичні інструменти. Енииклопедія украӥнознавства. Загальна частина. Репринтне відтворення видання 1949 р. Перевидання в Україні. Київ : Віпол, 1994. Т. 1. C. 279-282 ; Nyzhankivsky N. Folk instruments. Ukraine. A Concise Encyclopaedia / Edit. by V. Kubijovyč. Toronto : University of Toronto pres, 1963. Vol. I. P. 379-383. 
Енциклопедія украӥнськоӥ діаспори (далі - EUD) була започаткована в 1987 р. як 7-томний глобальний проєкт, призначений охопити українців, які проживають у всьому світі, за межами України. Його головним редактором був Василь Маркусь із Чикаго. НТШ у США та Фонд друзів Енциклопедії України (США) уклали угоду з редактором EUD про фінансування проєкту. Глобальний проєкт EUD видав лише T. 4. Австралія, Азія та Африка, який був опублікований у 1995 р. в Києві НТШ США та Національною академією наук України.

Робота над Т. 1. Сполучені Штати Америки розпочалася у 2006 p. У 2009 р. НТШ США (Нью-Йорк - Чикаго) опублікувало Книгу 1 $(\mathrm{A}-\mathrm{K})$ т. 1 , а у 2012 р. Книгу 2 (Л - Р). Книга 3 (С - Я) т. 1 закінчена у 2018 p. ${ }^{51}$ Музикознавчі статті до цих томів писали Вірко Балей, Андрій Горняткевич, Альберт Кіпа, Степан Максимюк, Роман Савицький, мол., Наталя Соневицька, Андрій Шуль та ін.

Музикознавці діаспори працювали над укладанням украӥнських музичних підручників, словників, розробкою термінології.

Осип Залеський видав у 1971 р. в Мюнхені «Малу українську музичну енциклопедію» ${ }^{52}$, Марія Дитиняк, Ігор та Наталя Соневицькі підготували біобібліографічні довідники про українських композиторів ${ }^{53}$. Довідник М. Дитиняк був одним із перших видань такого роду, адже західний світ отримав відомості про композиторів, які працюють в Україні, а українці довідалися про композиторів діаспори. Словник Соневицьких, виданий англійською мовою, значно розширив доступ до унікальних відомостей, адже подавав відомості про українських композиторів (XVII-XX ст.) як на материковій Україні, так i за іiі межами, вводив у науковий обіг закордонні джерела, невідомі в Україні факти із життя i творчості композиторів діаспори. I. Соневицький виступав редактором нового видання «Історії української музики» М. Грінченка ${ }^{54}$, пропам'ятних книг УМІА ${ }^{55}$.

Українські музикознавці співпрацювали із зарубіжними енциклопедіями, іноземними довідниками. Престижне свого часу одинадцятитомне видання «Музичного лексикона» за редакцією Гуго Рімана

\footnotetext{
${ }^{51}$ Енциклопедія української діяспори. Нью-Йорк ; Чікаго : НТШ в Америці, 2009. Т. 1 : Сполучені Штати Америки. Кн. 1 : А - К. 450 с. ; Енциклопедія української діяспори. Нью-Йорк ; Чікаго : НТШ в Америці, 2012. Т. 1 : Сполучені Штати Америки. Кн. 2 : Л - Р. 348 с. ; Енциклопедія української діяспори. Нью-Йорк ; Чікаго : НТШ в Америці, 2018. Т. 1 : Сполучені Штати Америки. Кн. 3 : С - Я. 525 с.

52 Залеський О. Мала українська музична енциклопедія. Мюнхен : Дніпрова хвиля, 1971. 125 с.

53 Дитиняк М. Українські композитори : біо-бібліографічний довідник. Едмонтон : Альбертський університет, 1986. 160 c. ; Sonevyts'kyi I., Palidvor-Sonevyts'ka N. Dictionary of Ukrainian Composers. L'viv: Union of Ukrainian Composers, 1997. 336 p.

${ }^{54}$ Грінченко М. Історія української музики. Київ : Спілка, 1922. 278 с. ; друге незмінене видання : Нью-Йорк : видання УМІ в Нью-Йорку, 1961. 192 с.

55 Пропам'ятна книга Українського музичного інституту в Америці з нагоди п'ятиліття його існування, 1952-1957 / ред. Р. Савицький. Філадельфія : УМІ, 1958. 99 с. ; Пропам'ятна книга Українського музичного інституту в Америці з нагоди десятиліття його існування, 1952-1962 / ред. I. Соневицький. Нью-Йорк : УМІ, 1963.77 с.
} 
(Riemann Hugo, "Music-Lexikon”. Berlin, 1929 р.) вийшло за допомогою Філарета Колесси й Осипа Залеського. Тут вміщено приблизно двадцять статей про українських музикантів. Одним із перших музикознавців, хто співпрацював з іноземними музичними енциклопедіями та словниками, був Федір Стешко. Він, зокрема, подав статтю про В. Барвінського до музичного словника, що вийшов у Брно (Чехо-Словаччина) ${ }^{56}$. Із німецьким довідником «Малі слов'янські біографії» (“Kleine Slavische Biographie“. Wiesbaden, 1958 р.) співпрацювала доктор Анна Наконечна, вмістивши солідні гасла про Д. Бортнянського, С. Воробкевича, А. Рудницького, Б. Лятошинського, Л. Ревуцького, В. Витвицького.

Плідно співпрацював із німецьким виданням «Музика в історії і в сучасності» ("Die Music in Geschichte and Gegenwart". Kassel, 1949-1968 pp. 14 частин) М. Антонович, чітко окреслюючи при гаслах про наших композиторів «український», подавав об'ємну бібліографію про них, також він опрацьовував українські гасла для фламандської музичної енциклопедіiі "Algemene Muziek-Encyclopedie" (Антверпен - Амстердам), для відомої "Music Encyclopedia” (Амстердам), для бельгійської та ін.

Український музикознавець і скрипаль Аристид Вирста активно дописував до низки європейських енциклопедій: французьких "Encyclopedie de la musique" у трьох томах (Париж, 1958-1961рр.), де надруковано приблизно 35 гасел-статей А. Вирсти про українських музикантів і окрему статтю про українську музику; та із "Larousse de la musique" (1957 p.).

Вірко Балей (США) співпрацював із біографічним словником російських/радянських композиторів за редакцією А. Го та Д.Феофанова $^{57}$.

Продовжуючи роботу своїх попередників в цьому аспекті, Роман Савицький мол. вніс до них суттєві уточнення про українських митців. Це англомовні українські енциклопедії США та Канади, а також вагомі в західному світі "The International Cyclopedia of Music and Musicians" (Нью-Йорк, 1975 р.) за редакцією Брюса Богла (Bruce Bohle) ${ }^{58}$, “The New Grove's Dictionary of Music and Musicians ” (Лондон, 1980 р.), до яких він звертався із пропозиціями виправити виявлені неточності чи помилки щодо української музики. Так, у 10-му виданні “The International Cyclopedia of Music and Musicians" Оскара Томпсона (Oscar Thompson, Нью-Йорк, редактор Б. Богл, 1975 р.) Р. Савицьким було вміщено 30 статей про українських музикантів, зокрема вперше - статті про М. Леонтовича, В. Барвінського, Р. Савицького. Відомості про

\footnotetext{
${ }^{56}$ Steško F., Barvinśkyi Vasyl. Pazdirkuv Hudebni Slovnik Naucny. II. Cast osobni. Brno : Nakladem Ol. Pazdirka, 1937. S. 43.

57 Baley V. Barvinsky Vasily. Biographical Dictionary of Russian. Soviet Composers / Editors-in-chief Allan Ho and Dmitry Feofanov. New York ; Westport, Connecticut ; London : Greenwood Press, 1989.

${ }_{58}^{5}$ Савицький Р. (мол.) В. Барвінський. Вибрані матеріали про його життя і творчість (з родинного архіву Р. Савицького). Кренфорд, США, 2000. С. 296.
} 
Д. Бортнянського, М. Лисенка, К. Данькевича, Л. Ревуцького та інших українських митців були вміщені ним у "Baker's Biographical of Musiciants" (Нью-Йорк, редактор Н. Слонімський (Nicholas Slonimsky) у нових редакціях - 6-е видання, 1978 р. та 7-ме видання 1984 р.) $)^{59}$. y "Biographical Dictionary of Russian / Soviet Composers" (Нью-Йорк, 1989 р., редактори А. Го і Д. Феофанов) ним було надруковано понад 100 статей про українських музикантів із розгорнутими бібліографіями та дискографіями, в "International Encyclopedia of women composers" (А. Cohen, Нью-Йорк, 1987 р.) було опубліковано статті про Н. Андрієвську й О. Андрєєву ${ }^{60}$. «3 1960 р., - пише дослідник, - мені довелося перевірити близько 250 таких джерел, і я переконався, що ті довідники погано повелися 3 українськими музиками» ${ }^{61}$. Неточності переважно стосувалися визначення національної приналежності: нерідко М. Березовського, Ф. Якименка, Б. Лятошинського, В. Косенка, Л. Ревуцького називали росіянами, В. Барвінського - мадяром, піаністку Любку Колессу, диригента i композитора Антона Рудницького поляками і т. п. «Де шукати причини таких викривлених інформацій?»запитує Р. Савицький і відповідає: «Вони не тільки у злій волі, у тенденційності інформаторів. Вони також у незорієнтованості далекого від України, передовсім англомовного світу, який легковірно сприймає тенденційні інформації» ${ }^{62}$. Виправляти ці «тенденції» він намагається в перелічених та інших виданнях. До думки вченого прислухались окремі недоліки були усунені. Цьому сприяла низка публікацій в англомовних часописах американського континенту про українське музичне мистецтво. Поява у 2009 р. першого тому нової енциклопедії української діаспори, яка присвячена США ${ }^{63}$, засвідчує продовження наполегливої праці вченого із впорядкування статей про діячів музичної культури в цій країні протягом XX ст., його невгамовну енергію. Роботу над багатотомною енциклопедію здійснює НТШ в Америці, а Р. Савицький як його дійсний член-кореспондент, подавши значну частину статей про діячів української музичної культури у США, продовжує традиції В. Витвицького, 3. Лиська й інших ученихмузикознавців, які працювали над ЕУ під керівництвом В. Кубійовича.

\footnotetext{
${ }^{59}$ Савицький Р. (мол). Українські музики у джерелах Заходу. Бібліографія украӥнознавства : бюлетень Комісії української бібліографії Міжнародної асоціації україністів / упор. і ред. вип. Ю. Ясиновський. Львів, 1994. Вип. 2 : Бібліографія та джерела музикознавства. С. 83.

${ }^{60}$ Немкович О. Українське музикознавство ХХ ст. як система наукових дисциплін : монографія. Київ, 2006. С. 397.

${ }_{61}$ Савицький Р. (мол). Українські музики у джерелах Заходу. Бібліографія українознавства : бюлетень Комісії української бібліографії Міжнародної асоціації україністів / упор. і ред. вип. Ю. Ясиновський. Львів, 1994. Вип. 2 : Бібліографія та джерела музикознавства. С. 81.

62 Савицький Р. (мол). Український музичний інститут Америки (УМІА). Бібліографія українознавства / упоряд. і ред. вип. Ю. Ясіновський. Львів : Міжнародна асоціація україністів, 1994. Вип. 2 : Бібліографія та джерела музикозавства. С. 84.

${ }_{63}$ Енциклопедія української діяспори. Т. 1 : Сполучені Штати Америки. Кн. 1 : А - К / гол. ред. Василь Маркусь ; співредактор Дарія Маркусь. Нью-Йорк ; Чикаго : НТШ в Америці, 2009. 433 с. 
Лео Вітошинський (Австрія) співпрацював 3 «Австрійським музичним лексиконом» (Österreichischen Musiklexikon / hrsg. von Rudolf Flotzinger, Dand 2. Wien, 2003), де, зокрема, опублікована його стаття про гітару в Австріі ${ }^{64}$. Він також виступав редактором окремих музичних творів. Так, у його редакції у 2001 р. світ побачила "Sonata classica" Альфереда Уля.

Отже, завдяки українським музикознавцям Ф. Стешку, О. Залеському, М. Антоновичу, А. Вирсті, В. Балею, І. Соневицькому, Р. Савицькому (мол.) та ін. статті про українську музику, ії творців та виконавців були внесені до світових енциклопедій та іноземних довідників, тим самим забезпечили інтеграцію української музичної культури у світовий культурний простір.

\section{3. Науково-організаційний вектор діяльності музикознавців діаспори та популяризація мистецтвознавчої науки}

Музикознавці активно співпращювали із журналами, газетами, насамперед діаспорними, пропагуючи українське музичне мистецтво.

Від початку свого перебування у США понад сорок років Василь Витвицький співпрацював із редакцією газети «Свобода» (Джерсі Сіті), де надруковані більшість його статей. У них автор регулярно порушував питання музично-громадського життя, друкував рецензії на концерти і друковані видання, які адресував широкому загалові читачів. Багато років В. Витвицький працював музичним редактором журналу «Сучасність» (Мюнхен - Нью-Йорк). Саме в цей період тут частіше друкуються статті на музичні теми як його самого, так і інших авторів В. Барвінського, Ю. Фіали, Р. Савицького, Я. Сорокера, В. Павловського. В. Витвицький дописував і до інших еміграційних видань: «Арка» (Мюнхен, Німеччина), «Детройтські вісті» (Детройт, США), «Вісті» (Сан Пауло, Міннесота, США), «Музичні вісті» (Міннеаполіс, США), «Новий Шлях» (Вінніпег, Канада), «Нові дні» (Торонто, Канада), польського журналу “Kultura” (Париж).

Критик пильно стежив за поступом музикознавчої думки в Україні і постійно рецензував музикознавчі збірки («Сучасна музика», «Українське музикознавство», окремі номери журналу «Музика»), монографії, що виходили в Україні, був добре обізнаний із музикознавчим доробком українських учених. В останні роки життя В. Витвицький завершує свої спогади «Музичними шляхами» ${ }^{65}$, у яких вдало поєднав історичну точність із легким стилем викладу.

Тематика його наукових $\mathrm{i}$ публіцистичних праць торкається шістнадцяти етносів.

\footnotetext{
${ }^{64}$ Вітошинський Л. Cantabile e ritmico. Про мистецтво гри на гітарі. Пер. 3 нім. Лідії Мельник. Львів : БаК, 2006. С. 23.

${ }^{65}$ Витвицький В. Музичними шляхами : спогади. Мюнхен : Сучасність, 1989. 215 с.
} 
Значним є внесок Романа Савицького (мол.) (1938-2015 pp.) ${ }^{66}$ у розвиток музикознавства, особливо в царині бібліографії та музичної критики. Він як дійсний член-кореспондент НТШ у Нью-Йорку, дійсний член УВАН у США, член НСКУ (із 2000 р.) усе своє подвижницьке життя присвятив служінню українському музичному мистецтву, активно вписуючи його в контекст світової культури.

Дослідником та пропагандистом української музики була Марія Дитиняк (Канада). Вона виголошує доповіді на різдвяних концертах, на ювілейному концерті з нагоди 130-річчя класика української музики М. Лисенка (1972р.), на всеканадській хоровій конференції (1989р.), на засіданнях Українського музичного товариства Альберти - «Звіт про музичний фестиваль в Саскатуні», «Про оперну співачку Свгенію Мірошниченко»; пише статті до тижневика «Українські вісті». Як член НТШ вона узагальнює діяльність Українського музичного товариства Альберти, хору «Дніпро», Фундації Тисячоліття хрещення України, а також здійснює характеристику композиторської творчості С. Яременка у виданнях Канадського НТШ «Західноканадський збірник» ${ }^{67}$. Протягом семи років вона викладала історію музики на курсах українознавства ім. I. Франка в Едмонтоні, сімнадцять років була коментатором української радіопрограми в Едмонтоні, яка пропагувала українську музику.

Музикознавці проводили активну організаційну роботу, брали участь у наукових конферениіях, виступали з доповідями, проводили творчі зустрічі та концерти.

Музикознавчу комісію при НТШ у США очолював І. Соневицький. На засіданнях Товариства вчений часто виступав із доповідями. Зокрема, 16 липня 1977 р. ним була виголошена доповідь «Тарас Шевченко і музика».

Осередок НТШ, що діє в Едмонтоні (Західна Канада) з 1955 р., зорганізував Канадський інститут українознавства, кафедру українського фольклору при Альбертському унверситеті, Канадську фундацію українських студій, Село української культурної спадщини, Альбертське товариство збереження української культури, Пластовий дім і дім «Верховина», українську книгарню, видання наукових «Західноканадських збірників» та багато іншого. Членами НТШ у Західній Канаді були діячі музичної культури: Марія Дитиняк, Андрій Горняткевич, Богдан Медвідський, Андрій Нагачевський, Валеріан

\footnotetext{
${ }^{66}$ Син відомого піаніста-педагога, мистецького діяча Романа Савицького (1907-1960рр.).

${ }^{67}$ Дитиняк М. Украӥнське музичне товариство. Західноканадський збірник / упор. ч. Я. Славутич. Едмонтон, Канада, 1998. Ч. 3. С. 128-140 ; Дитиняк М. Хор «Дніпро». Західноканадський збірник / упор. ч. Я. Славутич. Едмонтон, Канада, 1998. Ч. 3. С. 141-155 ; Дитиняк М. Фундація Тисячоліття хрещення України. Західноканадський збірник / упор. ч. Яр Славутич. Едмонтон : Канадське НТШ ; Друкарня Видав. спілки «Гомон України», 2000. Ч. 4. С. 82-97 ; Дитиняк М. Композиторська творчість Сергія Яременка. Західноканадський збірник. / упор. ч. Яр Славутич. Едмонтон : Канадське НТШ ; Друкарня Видав. спілки «Гомон України», 1975. Ч. 2. С. 264-271.
} 
Ревуцький ${ }^{68}$, у 2008 р. серед членів НТШ - Марія Дитиняк, Богдан Медвідський, Андрій Нагачевський, Браєн Черевик.

Сьогодні серед членів Управи НТШ Америки є відомі композитори Вірко Балей (перший віцепрезидент, він же керівник музикомистецтвознавчої секції), Леонід Грабовський (очолює контрольну комісію), член-кореспондентами НТШ є: оперна співачка Христина Карпевич, піаніст Павло Гінтов, композитор Андрій Легкий, скрипалька Соломія Сорока. НТШ Америки провели зустріч із композитором Валентином Сильвестровим (2015р.), презентації видань про Леоніда Грабовського (2018 р.).

Наукові доповіді музикознавців на конгресах та конференціях були однією з форм донесення їхніх здобутків до наукового загалу діаспори. На ювілейному науковому конгресі НТШ у США «Українська наука в діаспорі після 1945 р.», присвяченому 115-літтю заснування НТШ у Львові та 40-літтю відновлення його в еміграції» (історико-філософська секція, 4 грудня 1988 р.) член НТШ I. Соневицький виступив із доповіддю «Музикознавча і композиторська праця 3. Лиська». 10 грудня того ж року вчений мав доповідь «Історія музичної спадщини Артема Веделя» у циклі доповідей НТШ у США, 4 березня 1989 р. в домі НТШ прочитав доповідь «Шевченко і музика». Ще раніше на вшанування 35-річчя смерті К. Стеценка в 1957 р. вчений виступив 3 доповіддю в Народному домі Нью-Йорка для хористів «Думки» та інших слухачів ${ }^{69}$. У 2016 р. доповідь про музику Сергія Борткевича у НТШ Америки мав піаніст Павло Гінтов.

Аристид Вирста (Франція), перебуваючи в Нью-Йорку в 1958 р., виступає із двома доповідями, які супроводжував музичними ілюстраціями. Перша - у письменницькому об'єднанні «Слово» на тему «Українська музика у Франції», друга - в УВАН на тему «Сучасна українська музика». На Міжнародний музикологічний конгрес у Кельні (1958р.) він підготував доповідь про Ф. Якименка як представника східноєвропейського імпресіонізму в музиці $i^{70}$ У 1973 р. в м. Лестері (Велика Британія) на сковородинівському симпозіумі Остап Пицко 3 Ноттіггама виступив із доповіддю про Г. Сковороду як музиканта. Свою розвідку він збагатив виконанням кількох пісень українського філософа ${ }^{71}$.

Ювілейна наукова конференція на відзначення 150-річчя від дня народження М. Лисенка була проведена в Нью-Йорку 21 лютого 1993 p.

\footnotetext{
68 Західноканадський збірник / упор. ч. Яр Славутич. Едмонтон : Канадське НТШ, 1998. Ч. 3. C. 316.

${ }^{69}$ Невмируща пісня. Ювілейний альманах хору «Думка». 1949-1959. Нью-Йорк, 1960. С. 94.

${ }^{70}$ Штуль-Жданович О. А. Вирста повернувся до Парижу. Ціною крови / О. Штуль-Жданович. НьюЙорк ; Київ ; Торонто : Вид-во ім. Олени Теліги, 1997. С. 245, 246. Передрук за : Українське слово. 1958. Ч. 868. 29 червня. C. 147 .

${ }^{11}$ В молитві і пісні з Остапом Пицком / автор-упоряд. М. Пінковська. Київ : Bona mente, 2005.
} 
заходом УВАН і УІА, яку вела доктор мистецтвознавства Тамара Булат. 3 доповідями на ній виступили Василь Витвицький («М. Лисенко й I. Франко»), Леонід Грабовський («Зв’язок духовності політичних віршів Т. Шевченка 3 національним стилем М. Лисенка»), Галина Колесса («М. Лисенко та Ф. Колесса»), Т. Павловський («Хорові твори М. Лисенка в контексті української духовної музики»), Роман Савицький (мол.) («М. Лисенко в англомовному музикознавстві») ${ }^{72}$.

Наукові конференції, які відбуваються в Перемишлі (Польща) в останнє двадцятиліття, також висвітлюють питання музичної культури. Це конференції: «Перемишль і Перемиська земля протягом віків» (1995, 1998 рр.), «Проблеми кобзарського мистецтва» (1996р.), «Музика Галичини».

Важливою є діяльність архіву та бібліотеки НТШ у США, в архівній колекції яких знаходяться фонди композиторів О. Кошиця, А. Рудницького, І. Соневицького, співака К. Чічки-Андрієвського, бандуриста 3. Штокалка, Українського музичного інституту, які чекають свого наукового опрацювання.

Той факт, що в бібліотеці НТШ у США зберігаються монографії українських вчених, зокрема О. Козаренка та Г. Карась, які присвячені дослідженню української національної музичної мови та музичної культури української діаспори, засвідчує постійну увагу науковців діаспори до пульсування музикознавчої науки в Україні.

\section{ВИСНОВКИ}

Незважаючи на перешкоди (територіальна розпорошеність країнами світу, постійна еміграція, відсутність належної матеріальної бази та фінансування, українських академічних установ - наукових та навчальних закладів, бібліотек, музеїв, архівів), музикознавці діаспори наполегливо працювали над розвитком української науки. Заснування в 1948 році В. Кубійовичем Інституту Енциклопедії українознавства i залучення до співпраці відомих музикознавців В. Витвицького, 3. Лиська, А. Рудницького, Р. Савицького стало підгрунтям розвитку музикознавства за межами рідної землі. Здійснений огляд діяльності музикознавців діаспори впродовж семидесяти років засвідчує, що ними зроблено значний внесок у збереження і розвиток української музичної культури, який заслуговує на повагу і вивчення.

Встановлено, що основними напрямами наукового пошуку музикознавиів diacnopи були: історія української музичної культури й освіти; медієвістика й історія церковної музики; біографістика; фольклористика; музична лексикографія та біобібліографія; укладання

\footnotetext{
72 Гординська-Каранович Д. Відзначено 150-ліття Миколи Лисенка. Свобода. 1993. Ч. 98. 25 травня.

178
} 
енциклопедій, енциклопедії українознавства та дописи до зарубіжних енциклопедій, укладання українських музичних підручників, словників, розробка термінології.

Основними напрямами науково-організаційної діяльності були: співпраця із журналами, газетами, участь у міжнародних наукових конференціях, конгресах, виступи з доповідями, проведення творчих зустрічей та концертів; сприяння розвитку наукових осередків у вищих навчальних закладах світу; рецензування монографій та наукових видань; забезпечення діяльності архіву та бібліотеки НТШ у США.

В умовах незалежної України вивчення здобутку музикознавців діаспори отримало новий імпульс завдяки грунтовним дослідженням О. Гнатишин, У. Граб, Г. Карась, Н. Костюк, Ю. Медведика, Н. Сиротинської, Ю. Ясіновського. Усі вони актуалізують результати досліджень науковців діаспори у своїх працях.

\section{АНОТАЦІЯ}

Відтворення цілісності українського музикознавства актуалізує вивчення його діаспорної вітки, зокрема в контексті діяльності Наукового товариства імені Шевченка. Встановлено, що чільні постаті українського музикознавства діаспори повоєнного періоду (В. Витвицький, М. Антонович, 3. Лисько, А. Ольховський, П. Маценко, А. Рудницький, Р. Савицький та інші) збагатили його оригінальними науковими здобутками. Основний науково-дослідний напрям їхньої діяльності був спрямований на історичне музикознавство. Вони брали активну участь в укладанні енциклопедій, енциклопедії українознавства та дописували до закордонних енциклопедій, вводячи українську музику та іiі діячів у світовий культурний простір. Науково-організаційний вектор діяльності музикознавців діаспори стосувався їхньої співпраці 3 періодичними виданнями. 3 метою популяризації мистецтвознавчої науки вони брали участь у міжнародних наукових конференціях, конгресах, виступали 3 доповідями, проводили творчі зустрічі та концерти. Музикознавці сприяли розвитку наукових осередків у вищих навчальних закладах світу, забезпечували діяльність архіву та бібліотеки НТШ у США.

\section{ЛІТЕРАТУРА}

1. Антонович М. Дещо про українську церковну монодію та про назви «знаменний» і «київський» розспів. Науковий збірник Украӥнського вільного університету. Т. Х. Мюнхен, 1983. С. 147-170.

2. Антонович M. Значення української партесної музики для російської музичної культури XVII-XVIII ст. Збірник на пошану Григорія Китастого / упоряд. і редакція Я. Гурського. Нью-Йорк, 1980. C. 39-55. 
3. Антонович М. Кошиць Олександер Антонович - композитор церковної музики і диригент / відп. ред. П. Маценко. Вінніпег, 1975. 96 с.

4. Антонович М. Станислав Людкевич композитор, музиколог. Рим, 1980. 68 с. Передрук : Антонович М. Станислав Людкевич: композитор, музиколог / наук. ред. Ю. Ясиновський. Львів : Спілка композиторів України, 1999. 60 с. ; Антонович М. Станислав Людкевич: композитор, музиколог. Львів : Veritas, 2007. 64 с.

5. Антонович М. Питоменності українського церковного співу. Збірник праць Ювілейного конгресу у 1000-ліття Хрищення РусиУкраӥни у співпраці з Українським вільним університетом / ред. В. Янів. Мюнхен, 1988-1989. С. 458-474.

6. Антонович М. Поліфонічна музика в українських церквах у добі Козаччини. INTREPIDO PASTORI : науковий збірник на честь Блаженнішого Патріарха Йосифа в 40-ліття вступлення на галицький престіл. 01.11.1944. Рим, 1984. С. 595-612.

7. Антонович M. П'ятиголосна партесна Літургія - пам'ятка української музичної культури доби до Бортнянського. Богословія. Рим, 1973. Т. 37. С. 65-88, передрук під назвою «П'ятиголосна партесна Літургія - свідок української музичної культури з доби до Бортнянського. П'ятиголосна партесна Служба Божа невідомого автора / транскрипція та зведення в партитуру М. Антоновича ; ред. П. Маценко ; передрук музики С. Яременко. Вінніпег : Видання Колегії Св. Андрея у Вінніпезі при Манітобському ун-ті, 1979. С. 9-32 ; передрук: Антонович М. П'ятиголосна партесна Літургія - пам'ятка української музичної культури доби бароко. Записки НТШ : праиі музикознавчої комісї̈. Т. CCXXVI / ред. : О. Купчинський, Ю. Ясиновський. Львів, 1993. С. 57-74.

8. Антонович M. Musica sacra : збірник статей з історії української церковної музики / упор., наук. ред., передм. Ю. Ясиновський. Львів : Інт українознавства ім. І. Крип’якевича НАН України, 1997. 261 с.

9. В молитві і пісні з Остапом Пицком / автор-упоряд. М. Пінковська. Київ : Bona mente, 2005. 191 с.

10. Витвицький В. Історія музики. XVIII-XIX ст. Енциклопедія украӥнознавства. Загальна частина. Репринтне відтворення видання 1949 р. Перевидання в Україні. Київ : Віпол, 1995. Т. 3. С. 869-873.

11. Витвицький В. Максим Березовський. Життя і творчість. Джерзі Ситі : Вид-во М.П. Коць, 1974. 95 с. ; передрук : Витвицький В. Максим Березовський. Життя і творчість / ред. колегія : В. Гаюк, Я. Якубяк, Ю. Ясиновський ; наук. ред. Л. Кияновська. Львів : Логос, 1995. 110 с.

12. Витвицький В. Михайло Гайворонський: життя і творчість. НьюЙорк, 1954. 207 с. ; передрук : Витвицький В. Михайло Гайворонський: життя і творчість / ред. : С. Дзюпина, Ю. Ясіновський. Львів, 2001. 175 с. 
13. Витвицький В. Музикознавець Андрій Ольховський (1900-1969). Сучасність. 1978. № № 7-8. С. 191-202.

14. Витвицький В. Музичне виконавство. Енциклопедія українознавства. Загальна частина. Репринтне відтворення видання 1949 p. Перевидання в Україні. Київ : Віпол, 1995. Т. 3. С. 876-879.

15. Витвицький В. Музичними шляхами : спогади. Мюнхен : Сучасність, 1989. 215 с.

16. Вітошинський Л. Cantabile e ritmico. Про мистецтво гри на гітарі. Пер. $з$ нім. Лідії Мельник. Львів : БаК, 2006. 284 с.

17. Гнатишин О. Історичний вимір українських музично-теоретичних концепцій : монографія. 2-ге вид. Львів : Вид-во Львівської політехніки, 2018. $600 \mathrm{c}$.

18. Горак Я. Протоколи засідань музикознавчої комісії НТШ. Украйнська музика. Львів, 2018. № 2 (28). С. 121-134.

19. Гординська-Каранович Д. Відзначено 150-ліття Миколи Лисенка. Свобода. 1993. Ч. 98.25 травня.

20. Граб У. Мирослав Антонович: інтелектуальна біографія. Еміграційне музикознавство в українському культуротворенні повоєнних десятиліть: монографія. Львів : Вид-во Українського католицького університету, 2018. 456 с.

21. Грінченко М. Історія української музики. Київ : Спілка, 1922. 278 с. Друге незмінене видання : Нью-Йорк : Видання УМІ в Нью-Йорку, 1961. $192 \mathrm{c.}$

22. Дитиняк М. Композиторська творчість Сергія Яременка. Західноканадський збірник / упор. ч. Яр Славутич. Едмонтон : Канадське НТШ ; Друкарня Видав. спілки «Гомон України», 1975. Ч. 2. С. 264-271.

23. Дитиняк М. Українське музичне товариство. Західноканадський збірник / упор. ч. Я. Славутич. Едмонтон, Канада, 1998. Ч. 3. С. 128-140.

24. Дитиняк М. Українські композитори : біо-бібліографічний довідник. Едмонтон : Альбертський університет, 1986. 160 с.

25. Дитиняк М. Фундація Тисячоліття хрещення України. Західноканадський збірник / упор. ч. Яр Славутич. Едмонтон : Канадське НТШ ; Друкарня Видав. спілки «Гомон України», 2000. Ч. 4 С. 82-97.

26. Дитиняк М. Хор «Дніпро». Західноканадський збірник / упор. Я. Славутич. Едмонтон, Канада, 1998. Ч. 3. С. 141-155.

27. Духовні твори Артемія Лукіяновича Веделя / ред. І. Соневицький. Нью-Йорк, 1985.

28. Енциклопедія української діяспори. Т. 1 : Сполучені Штати Америки. Кн. 1 : А - К. Нью-Йорк ; Чікаго : НТШ в Америці, 2009. $433 \mathrm{c}$.

29. Енциклопедія української діяспори. Т. 1 : Сполучені Штати Америки. Кн. 2 : Л - Р. Нью-Йорк ; Чікаго : НТШ в Америці, 2012. 348 с. 
30. Енциклопедія української діяспори. Т. 1 : Сполучені Штати Америки. Кн. 3 : С - Я. Нью-Йорк ; Чікаго : НТШ в Америці, 2018. 525 с.

31. Залеський О. Мала українська музична енциклопедія. Мюнхен : Дніпрова хвиля, 1971. 125 с.

32. Західноканадський збірник / упор. ч. Яр Славутич. Едмонтон : Канадське НТШ, 1998. Ч. 3. 384 с.

33. Карась Г. Музична культура української діаспори у світовому часопросторі XX ст. : монографія. Івано-Франківськ : Тіповіт, 2012. $1164 \mathrm{c}$.

34. Ковалів I. Василь Барвінський: нарис життя і творчости. Торонто : Муз. ін-т ім. М. Лисенка, 1964. 13 с.

35. Купчинський Р. Ми йдемо в бій : повний збірник пісень / записав, упор. і зред. І. Соневицький. Нью-Йорк : Червона калина, 1977. 144 с.

36. Лисько 3. Історія музики. XI-XVII ст. Енщиклопедія украӥнознавства. Загальна частина. Репринтне відтворення видання $1949 \mathrm{p}$. Перевидання в Україні. Київ : Віпол, 1995. Т. 3. С. 868-869.

37. Лисько 3. Народна музика. Енщиклопедія украӥнознавства. Загальна частина. Репринтне відтворення видання 1949 р. Перевидання в Україні. Київ : Віпол, 1994. Т.1. С. 273-279.

38. Лисько 3. Український гімн. Енцииклопедія украйнознавства. Загальна частина. Репринтне відтворення видання 1949 р. Перевидання в Україні. Київ : Віпол, 1994. Т. 1. С. 33-34.

39. Маценко П. Засади творчости О. Кошиця. Вінніпег, 1950. 14 с.

40. Маценко П. Нариси до історії української церковної музики. Роблин ; Вінніпег : Видання М. Т. Б., 1967. 151 с. ; Маценко П. Нариси до історії української церковної музики. 2-ге репринт. вид. Роблин ; Вінніпег, 1968. Київ : Муз. Україна, 1994. 152 с.

41. Маценко П. Нариси 3 історії української церковної музики. Вінніпег : Колегія Св. Андрея у Вінніпезі, 1993. 172 с.

42. Маценко П. Склад та технічна будова мелодій київського розспіву в Почаївському ірмолоєві вид. 1775 р. : дис. Відень, 1930-1932 ; Павло Маценко : музиколог, композитор і громадський діяч : збірник на пошану 90-ліття народин / упор. і зредаг. В. Верига. Торонто : вид УНО Канади, 1992. С. 127-238.

43. Маценко П. Українські канти. Вінніпег: накладом Т-ва «Волинь», 1981. 22 c.

44. Маценко П. Українська церковна музика. Ювілейний збірник наукових праць Канадського Наукового товариства імені Шевченка в 100-річчя Наукового товариства імені Шевченка і у 25-річчя Наукового товариства імені Шевченка в Канаді / ред. : Р. Біланюк, Б. Стебельський. Торонто, Онтаріо, Канада : Гомін України, 1997. С. 136-141. 
45. Маценко П. Якименко Федір Степанович. Вінніпег : ОУКО, 1954. $18 \mathrm{c}$.

46. Маценко П. С. Яременко - композитор. Вінніпег : Новий шлях, 1974. $32 \mathrm{c}$.

47. Мирослав Скала-Старицький (Miro Skala). Перший тенор Королівської опери «Ля Моне» у Брюсселі : автобіографічні нариси / ред., упоряд І. Соневицький. Львів, 2000. 95 с.

48. Наукове товариство імені Шевченка. URL: https://uk.wikipedia.org/ wiki/Наукове_товариство_імені_Шевченка.

49. Невмируща пісня. Ювілейний альманах хору «Думка». 1949-1959. Нью-Йорк, 1960. 112 с.

50. Недільский I. Вибрані твори для мішаного хору a capella / за ред. Ігоря Соневицького. Ню-Йорк : Українська музична фундація, 1982.98 с.

51. Немкович О. Українське музикознавство XX ст. як система наукових дисциплін : монографія. Київ, 2006. 534 с.

52. Нижанківський Н. Народні музичні інструменти. Енцииклопедія украйнознавства. Загальна частина. Репринтне відтворення видання 1949 р. Перевидання в Україні. Київ : Віпол, 1994. Т. 1. С. 279-282.

53. Оленський $€$. Історія музики. $\mathrm{XX}$ ст. Енщиклопедія украйнознавства. Загальна частина. Репринтне відтворення видання 1949 р. Перевидання в Україні. Київ : Віпол, 1995. Т. 3. С. 873-876.

54. Оленський $€$. Музикознавство і музичне шкільництво. Енцикллопедія украӥнознавства. Загальна частина. Репринтне відтворення видання 1949 р. Перевидання в Україні. Київ : Віпол, 1995. Т. 3. С. 866-868.

55. Оленський Є. Історія музики. ХX ст. Енщиклопедія українознавства. Загальна частина. Репринтне відтворення видання 1949 p. Перевидання в Україні. Київ : Віпол, 1995. Т. 3. С. 873-876.

56. Пропам'ятна книга Українського музичного інституту в Америці 3 нагоди п'ятиліття його існування, 1952-1957 / ред. Р. Савицький. Філадельфія : накладом УМІ, 1958. 99 с.

57. Пропам'ятна книга Українського музичного інституту в Америці 3 нагоди десятиліття його існування, 1952-1962 / ред. І. Соневицький. Нью-Йорк : УМІ, 1963. 77 с.

58. П’ятиголосна партесна Служба Божа невідомого автора / транскрипція та зведення в партитуру - М. Антонович ; ред. П. Маценко ; передрук музики С. Яременко. Вінніпег : видання Колегії Св. Андрея у Вінніпезі при Манітобському ун-ті, 1979. 79 с.

59. Рудницький А. 3 нових видань. Витвицький Василь. Максим Березовський. Життя і творчість. Джерзі Ситі : В-во М.П. Коць, 1974. С. 94. Свобода. 1975. Ч. 102. 29 травня.

60. Рудницький А. Українська музика : історико-критичний огляд. Мюнхен : Дніпрова хвиля, 1963. 406 с. 
61. Рудницький А. Про музику і музик. Ню-Йорк ; Париж ; Сідней ; Торонто : НТШ, Б-ка українознавства, 1980. Ч. 39.336 с.

62. Савицький Р. (мол.). В. Барвінський. Вибрані матеріали про його життя і творчість (з родинного архіву Р. Савицького). Кренфорд, США, $2000.317 \mathrm{c}$.

63. Савицький Р. (мол). Український музичний інститут Америки (УМІА). Бібліографія украӥнознавства. / упоряд. і ред. вип. Ю. Ясіновський. Львів : Міжнародна асоціація україністів, 1994. Вип. 2. С. 69-75.

64. Савицький Р. (мол). Українські музики у джерелах Заходу. Бібліографія украӥнознавства / упор. і ред. вип. Ю. Ясиновський. Львів, 1994. Вип. 2. С. 81-86.

65. Сивохіп В. Етномузиколог Зиновій Лисько - репрезентант i продовжувач фольклористичної традиції Філарета Колесси. Родина Колессів у духовному та культурному житті України кіния XIXХХ століття (з нагоди 130-річчя від дня народження академіка Філарета Колесси та 100-річчя від дня народження академіка Миколи Колесси) : збірник наукових праць та матеріалів. Львів, 2005. С. 229-237.

66. Соневицький I. Артем Ведель і його музична спадщина. УВАН у США. Музикологічна секція. Ротапринт. Нью-Йорк, 1966. 177 с.

67. Соневицький I. Лекції з історії української церковної музики. Рим, 1975.

68. Соневицький I. Композиторська спадщина Нестора Нижанківського. Рим : Богословія, Ч. 45, 1973. 34 с.

69. Терен-Юськів Т. Національно-державна мотивація творчості С. Людкевича. Лондон : Укр. видавн. спілка, 1984. 80 с.

70. Черевик Б. Звуки прерій : виставка, присвячена українській інстументальній музиці в Альберті. Західноканадський збірник / ред. М. Сорока. Едмонтон ; Острог, 2008. Ч. 5. С. 451-455.

71. Черевик Б. Українська інструментальна музика в Альберті. Західноканадський збірник / упор. Яр Славутич. Едмонтон : Канадське НТШ ; Друкарня Видав. спілки «Гомон України», 2000. Ч. 4. С. 325-342.

72. Штуль-Жданович О. А. Вирста повернувся до Парижу. Ціною крові / О. Штуль-Жданович. Нью-Йорк ; Київ ; Торонто : Вид-во ім. Олени Теліги, 1997. С. 245, 246.

73. Шуль А. Д-р Василь Витвицький: музикознавець як культуролог. Доповідь на конференції в пошану В. Витвицького (машинопис). НьюЙорк, 2001. 31 березня.

74. Фіяла Ю. Сучасний композитор і проблеми музичної творчости ХХ ст. Сучасність. Мюнхен, 1982. Ч. 4-5 (256-257). С. 92-103.

75. Antonowytcz M. Die motette Benedicta es von Josquin des Prez und die Messen super Benedicta von Willaert, Palestrina, de la Hêle und de Monte. Utrecht, 1951. 126 S. 
76. Antonowytcz M. Oekraïne en de Bezantijnse ritus. Hoensbroek, 2000. 367 Blz.

77. Antonowytcz M. The Chants from Ukrainian Heirmologia. Bilthowen, 1974. $203 \mathrm{p}$.

78. Antonowytcz M. Ukrainische geistliche Musik. München, 1990. 374 S.

79. Baley V. Barvinsky Vasily. Biographical Dictionary of Russian. Soviet Composers / Editors-in-chief Allan Ho and Dmitry Feofanov. New York ; Westport, Connecticut ; London : Greenwood Press, 1989.

80. Cherwick B. Muzyky: Ukrainian bands in Western Canada. Mіграиійні рухи із Західної України до Західної Канади : матеріали спільних конференцій : Міжнародної конферениії «Еміграчія населення західноукраӥнських земель до Північної Америки на рубежі XIX-XX cm. Ï̈ роль в освоєнні канадського заходу». До 100-річчя украӥнської еміграчії, м. Чернівиі, 1990 p. / ред. : О. Макар, Р. Білаш. Едмонтон : Канадський центр української культури та етнографії, Альбертський університет ; Відділ охорони історичних пам'яток, Міністерство громадського розвитку Альберти, 2002. С. 299-305.

81. Cherwick B. The Ukrainian Tsymbaly: Hammered Dulcimer Playing Among Ukrainians in Alberta: in partial fulfillment of the requirements for the degree of Master of Arts in Ukrainian Folklore. University of Alberta, Canada,1992. $147 \mathrm{p}$.

82. Cherwick B. Polkas on the Prairies : Ukrainian Music and the Construction of Identity. Doctor of Philosophy. University of Alberta, Canada,1999. $226 \mathrm{p}$.

83. Lysko Z. History of Ukrainian Music: Eleventh to Seventeenth Centuries. Ukraine. A Concise Encyclopaedia / Edit. by V. Kubijovyč. Vol. II. Toronto : University of Toronto Press, 1971. P. 579-582.

84. Lysko Z. Folk music. Ukraine. A Concise Encyclopaedia / Edit. by V. Kubijovyč. Vol. I. Toronto : University of Toronto pres, 1963. P. 371-378.

85. Nyzhankivsky N. Folk instruments. Ukraine. A Concise Encyclopaedia / Edit. by V. Kubijovyč. Vol. I. Toronto : University of Toronto pres, 1963. P. 379-383.

86. Olkhovsky A. History of Ukrainian Music: Twentieth Century. Ukraine. A Concise Encyclopaedia / Edit. by V. Kubijovyč. Vol. II. Toronto : University of Toronto Press, 1971. P. 588-593.

87. Olkhovsky A. Musical education; Musicology. Ukraine. A Concise Encyclopaedia / Edit. by V. Kubijovyč. Vol. II. Toronto : University of Toronto Press, 1971. P. 582-588, 593-600.

88. Sonevyts'kyi I., Palidvor-Sonevyts'ka N. Dictionary of Ukrainian Composers. L'viv : Union of Ukrainian Composers, 1997. 336 p.

89. Steško F., Barvinśkyi Vasyl. Pazdirkuv Hudebni Slovnik Naucny. II. Cast osobni. Brno : Nakladem Ol. Pazdirka, 1937. S. 43. 
90. Wytwycky W. History of Ukrainian Music. Eighteenth and Nineteenth Centuries. Ukraine. A Concise Encyclopaedia / Edit. by V. Kubijovyč. Vol. II. University of Toronto pres, 1971. P. 582-588.

91. Wytwycky W. Musical performance. Ukraine. A Concise Encyclopaedia / Edit. by V. Kubijovyč. Vol. II. University of Toronto pres, 1971. P. 593-600.

\section{Information about author:}

Karas H. V.,

Doctor of Arts, Professor,

Professor at the Department of Music Education and Conducting Methods

Vasyl Stefanyk Precarpathian National University 57, Shevchenko str., Ivano-Frankivsk, 76018, Ukraine 